\title{
REFORMASI PENEGAKAN HUKUM PERSPEKTIF HUKUM PROGRESIF
}

\author{
Lutfil Ansori \\ Fakultas Syari'ah dan Hukum Universitas Islam Negeri Sunan Ampel Surabaya \\ Email: fil.ansori@gmail.com
}

\begin{abstract}
Abstrak
Tulisan ini bertujuan untuk menelaah reformasi dan optimalisasi penegakan hukum di dalam institusi penegak hukum ditinjau dari prespektif hukum progresif. Wajah hukum di Indonesia dewasa ini dihadapkan pada persoalan yang sangat komplek dalam proses penegakan hukum. Maka reformasi penegakan hukum merupakan jawaban terhadap bagaimana hukum di Indonesia diselenggarakan dalam kerangka pembentukan negara hukum yang dicita-citakan. Reformasi penegakan hukum idealnya harus dilakukan melalui pendekatan sistem hukum (legal system), yang meliputi sub sistem substansi hukum (legal substance), sub sistem struktur hukum (legal structure), dan subsistem budaya hukum (legal culture). Dalam konteks reformasi institusi penegakan hukum, reformasi institusi yang ideal harus mengacu pada tiga orientasi utama, yaitu prinsip demokrasi, rule of law, dan hak asasi manusia. Reformasi institusi tersebut harus dibarengi dengan perubahan paradigma dari cara berfikir hukum tektual ke hukum progresif. Hal ini dapat diwujudkan apabila reformasi institusi penegak hukum konsisten dalam mewujudkan perubahan pada aspek kultural yang merupakan muara dari perubahan aspek struktural dan instrumental.
\end{abstract}

Kata kunci: Reformasi, Penegakan Hukum, Hukum Progresif

\begin{abstract}
This articel aim for examine reformation and optimalisation of law enforcement at law enforcerment institution in terms of progresive law perspective. the law face in Indonesia today is faced a complex problem on law enforcement process. Yet, Reformation on law enforcement is the answer to how the law in Indonesia is actuated within frame work of estabilishment an aspired state of law. Law enforcement reformation ideally must be done through legal system approach, that covered legal substance sub system, legal structure sub system, and legal culture subsystem. in the context of law enforcement institution reformation, institution reformation ideally based on three main orientation, which is democration principal, rule of law, and human rights. That institution reformation must be done with changing paradigm from the way of textual legal thinking to progresive legal thinking. It can be formed if reformation of law enforcement institution, consistent in bringing about changing cultural aspect that comes from changing structural aspect and instrumental aspect.
\end{abstract}

Keywords: Reformation, Law Enforcement, Progresive Law

\section{A. PENDAHULUAN}

\section{Latar Belakang}

Hukum dan masyarakat adalah suatu hal yang tidak bisa dipisahan satu sama lain. Berlakunya hukum itu berlangsung di dalam suatu tatanan sosial yang disebut dengan masyarakat. Pameo bangsa romawi yang menyatakan ubi societas ibi ius telah menggambarkan betapa eratnya 
hubungan antara hukum dan masyarakat. ${ }^{1}$ Oleh karena itu hukum harus ditempatkan sebagai kerangka proses yang terus mengalami perkembangan (law in the making).

Hukum bukanlah dogma yang bersifat final. Hukum tentu saja akan bergerak secara simultan sesuai dengan tuntutan zamannya (continue on progress). Sebagai contoh, tentang perbuatan melawan hukum dalam "Arrest Hoge Raad" atau putusan Mahkamah Agung Belanda pada bulan Januari 1919 atau sering juga diistilahkan dengan "Revolusi Bulan Januari". Putusan tersebut tidak hanya mendefinisikan ulang terhadap makna perbuatan melawan hukum, tapi juga memberikan suatu lompatan besar dalam sejarah perkembangan hukum yang selalu mengalami progresifitas. Mahkamah Agung Belanda pada tanggal 13 Januari 1919 membuat putusan yang mengatakan bahwa, "melawan hukum tidak hanya bertentangan dengan undang-undang, tapi juga bertentangan dengan tata susila dan kepatutan menurut masyarakat". ${ }^{2}$

Hal ini menjadi landasan kuat yang menegaskan bahwa hukum harus mengalami proses adaptasi sesuai dengan zamannya masing-masing. Inilah salah satu makna dasar dari hukum progresif. Hukum bukanlah sebagai sebuah sistem yang stagnan dan status quois, namun mengikuti jejak perkembangan sejarah sesuai dengan tuntunan perubahan sosial masyarakat. $^{3}$

Masyarakat menghendaki hukum tidak lagi menjadi alat untuk kepentingan penguasa, ataupun kepentingan politik. Oleh karena itu dibutuhkan penegakan hukum yang berkeadilan. Sejalan dengan hal tersebut, realita dalam penegakan hukum seringkali mengabaikan rasa keadilan masyarakat mengingat secara tekstual substansi hukum lebih mensyaratkan pada adanya kepastian hukum. Hal tersebut menjadi tantangan tersendiri bagi aparat penegak hukum dalam penegakan hukum di Indonesia.

Dalam konteks itu, reformasi penegakan hukum merupakan jawaban terhadap bagaimana hukum di Indonesia diselenggarakan dalam kerangka pembentukan negara hukum yang dicita-citakan.

Reformasi secara gramatikal diartikan sebagai membentuk, menyusun, dan mempersatukan kembali. ${ }^{4}$ Secara lebih sederhana reformasi berarti perubahan format, baik pada struktur maupun aturan main (rule of the game) ke arah yang lebih baik. Pada kata reformasi terkandung pula dimensi dinamik berupa upaya perombakan dan penataan yakni perombakan tatanan lama yang korup dan tidak efisien (dismantling the old regime) dan penataan suatu tatanan baru yang lebih demokratik, efisien, dan berkeadilan 2006, hlm. 3

1 Mochtar Kusumaatmadja, Konsep-Konsep Hukum Dalam Pembangunan, Bandung: Alumni,

2 Satjipto Rahardjo, Hukum Progresif, Sebuah Sintesa Hukum Indonesia, Yogyakarta: Genta Publishing, 2009, hlm. 61

3 Ibid., hlm. 18

4 W.T. Cunningham, Nelson Contemporary English Dictionary, Canada: Thompson and Nelson Ltd, 1982, hlm. 422 
sosial (reconstructing the new regime). Selain itu, kata reformasi memuat nilai-nilai utama yang menjadi landasan dan harapan proses bernegara dan bermasyarakat.

Sedangkan penegakan hukum dalam bahasa Inggris disebut dengan law enforcement. Menurut Black's Law Dictionary, law enforcement diartikan sebagai the act of putting something such as a law into effect; the execution of law; the carriying out of a mandate or command. ${ }^{5}$ Secara sederhana Muladi menyatakan bahwa penegakan hukum (law enforcement) merupakan usaha untuk menegakkan norma-norma hukum dan sekaligus nilai-nilai yang ada di belakang norma tersebut. Dengan demikian para penegak hukum harus memahami benar spirit hukum (legal spirit) yang mendasari peraturan hukum yang harus ditegakkan dan dalam hal ini akan berkaitan dengan berbagai dinamika yang terjadi dalam proses pembuatan perundang-undangan (law making process). ${ }^{6}$

Reformasi penegakan hukum idealnya harus dilakukan melalui pendekatan sistem hukum (legal system). Sudikno Mertokusomo mengartikan sistem hukum adalah suatu kesatuan yang terdiri dari unsurunsur yang mempunyai interaksi satu sama lain dan bekerja sama untuk mencapai tujuan kesatuan tersebut ${ }^{7}$ Menurut Lawrence M. Friedman, dalam setiap sistem hukum terdiri dari 3 (tiga) sub sistem, yaitu sub sistem substansi hukum (legal substance), sub sistem struktur hukum (legal structure), dan subsistem budaya hukum (legal culture). ${ }^{8}$ Substansi hukum meliputi materi hukum yang diantaranya dituangkan dalam peraturan perundang-undangan. Struktur hukum menyangkut kelembagaan (institusi) pelaksana hukum, kewenangan lembaga dan personil (aparat penegak hukum). Sedangkan kultur hukum menyangkut perilaku (hukum) masyarakat. Ketiga unsur itulah yang mempengaruhi keberhasilan penegakan hukum di suatu masyarakat (negara), yang antara satu dengan lainnya saling bersinergi untuk mencapai tujuan penegakan hukum itu sendiri yakni keadilan.

Salah satu subsistem yang perlu mendapat sorotan saat ini adalah struktur hukum (legal structure). Hal ini dikarenakan struktur hukum memiliki pengaruh yang kuat terhadap warna budaya hukum. Budaya hukum adalah sikap mental yang menentukan bagaimana hukum digunakan, dihindari, atau bahkan disalahgunakan. Struktur hukum yang tidak mampu menggerakkan sistem hukum akan menciptakan ketidakpatuhan (disobedience) terhadap hukum. Dengan demikian struktur hukum yang menyalahgunakan hukum akan melahirkan budaya menelikung dan 1990

5 Henry Campbell Black, Black's Law Dictionary, Edisi VI, St. Paul Minesota: West Publishing,

6 Muladi, Hak Asasi Manusia, Politik dan Sistem Peradilan Pidana, Cet. II, Semarang: Badan Penerbit Universitas Diponegoro, 2002, hlm. 69

7 Sudikno Mertokusumo, Mengenal Hukum, Yogyakarta: Liberty, 1991, hlm. 102

8 Lawrence M. Friedman, Hukum Amerika: Sebuah Pengantar, Terjemahan dari American Law An Introduction, 2nd Edition, Alih Bahasa: Wisnu Basuki, Jakarta: Tatanusa, 2001, hlm. 6-8 
menyalahgunakan hukum. Berjalannya struktur hukum sangat bergantung pada pelaksananya yaitu aparatur penegak hukum.

Menurut Soerjono Soekanto, ruang lingkup dari istilah "penegak hukum" luas sekali, oleh karena mencakup mereka yang secara langsung dan secara tidak langsung berkecimpung di bidang penegakan hukum. Dari pengertian yang luas tadi, Soerjono Soekanto lebih membatasi pengertiannya yaitu kalangan yang secara langsung berkecimpung dalam bidang penegakan hukum yang tidak hanya mencakup law enforcement, akan tetapi juga peace maintenance. Dengan demikian mencakup mereka yang bertugas di bidang-bidang kehakiman, kejaksaan, kepolisian, kepengacaraan, dan pemasyarakatan. ${ }^{9}$

Penegakan hukum dalam konteks hukum pidana dilaksanakan melalui sistem peradilan pidana yang pelaksanaannya terdiri dari setidaknya 4 (empat) komponen, yakni Kepolisian, Kejaksaan, Pengadilan, dan Pemasyarakatan. Keempat komponen tersebut telah diatur dalam UndangUndang Nomor 8 tahun 1981 tentang Hukum Acara Pidana (KUHAP).

\section{Rumusan Masalah}

Dari uraian latar belakang masalah diatas, dalam tulisan ini akan dibahas tentang reformasi institusi penegakan hukum dalam prespektif hukum progresif. Permasalahan pokok yang akan dijawab dalam tulisan ini adalah bagaimana reformasi dan optimalisasi dalam penegakan hukum di dalam institusi penegak hukum ditinjau dari prespektif hukum progresif.

\section{B. PEMBAHASAN}

\section{Reformasi Hukum}

Wajah hukum di Indonesia dewasa ini dihadapkan pada persoalan yang sangat komplek. Praktik penyelewengan dalam proses penegakan hukum seperti, mafia hukum dan peradilan, peradilan yang diskriminatif atau rekayasa proses peradilan merupakan realitas yang gampang ditemui dalam penegakan hukum di negeri ini. Peradilan yang diskriminatif menjadikan hukum di negeri ini persis seperti yang dideskripsikan Plato bahwa hukum adalah jaring laba-laba yang hanya mampu menjerat yang lemah tetapi akan robek jika menjerat yang kaya dan kuat (laws are spider webs, they hold the weak and delicated who are caught in their meshes but are torn in pieces by the rich and powerful). Buramnya wajah hukum merupakan anak kandung penegakan hukum (law enforcement) yang stagnan. Kalaupun hukum telah dicoba ditegakkan maka penegakannya yang diskriminatif. ${ }^{10}$

9 Soerjono Soekanto, Faktor-Faktor yang Mempengaruhi Penegakan Hukum, Jakarta: PT Raja Grafindo Persada, 2007, hlm. 19

10 Moh. Mahfud MD., "Keniscayaan Reformasi Hukum: Upaya Menjaga Jati Diri Dan Martabat Bangsa", Makalah disampaikan dalam Konvensi Kampus VI dan Temu Tahunan XII Forum Rektor Indonesia (FRI), Pontianak: Universitas Tanjungpura, 9 Januari 2010, hlm. 2 
Oleh karena itu, reformasi hukum dalam konteks ini menjadi sebuah keniscayaan. Reformasi hukum merupakan jawaban terhadap bagaimana hukum di Indonesia diselenggarakan dalam kerangka pembentukan negara hukum yang dicita-citakan. Hukum mengemban fungsi ekspresif yaitu mengungkapkan pandangan hidup, nilai-nilai budaya dan nilai keadilan. Selain itu hukum mengemban fungsi instrumental yaitu sarana untuk menciptakan dan memelihara ketertiban, stabilitas dan prediktabilitas, sarana untuk melestarikan nilai-nilai budaya dan mewujudkan keadilan, sarana pendidikan serta pengadaban masyarakat dan sarana pembaharuan masyarakat (mendorong, mengkanalisasi dan mengesahkan perubahan masyarakat). ${ }^{11}$

Di Indonesia, tujuan hukum adalah untuk membentuk suatu pembentukan negara Indonesia yang melindungi segenap bangsa Indonesia dan seluruh tumpah darah indonesia dan untuk memajukan kesejahteraan umum, mencerdaskan kehidupan bangsa serta ikut melaksanaan ketertiban dunia yang berdasarkan kemerdekan, perdamaian abadi dan keadilan sosial. Jika hukum tidak lagi dapat bekerja sesuai tujuan dan sebagaimana fungsinya maka itu menandakan upaya-upaya reformasi hukum sudah waktunya dilakukan. Roscoe Pound misalnya, telah mengatakan bahwa hukum berfungsi sebagai alat rekayasa pembaruan masyarakat (law as a tool of social engineering), tetapi apabila dalam kenyataannya di Indonesia telah bergeser menjadi alat rekayasa pembenaran korupsi (law as tool of corruption engineering) maka jelas diperlukan reformasi terhadapnya. Reformasi hukum bukan saja diartikan sebagai penggantian atau pembaruan perundang-undangan, akan tetapi juga perubahan asumsi dasar dari sebuah tata hukum yang berlandaskan ide-ide diskriminatif dan kesenjangan sosial menjadi ide-ide persamaan di depan hukum dan keadilan sosial. ${ }^{12}$

Misi yang diemban dalam rangka reformasi hukum adalah terciptanya hukum yang tertib dan berkeadilan namun tetap senantiasa mampu mendorong pembangunan bagi peningkatan kesejahteraan masyarakat. Tujuan utama yang hendak dicapai dalam kerangka reformasi hukum adalah tegaknya supremasi hukum yang berkeadilan dalam masyarakat. Namun demikian, realita dalam praktek penegakan hukum senantiasa menunjukkan hukum yang meninggalkan rasa keadilan. Ketiadaan keadilan ini merupakan akibat dari pengabaian hukum (diregardling the law), ketidakhormatan pada hukum (disrespecting the law), ketidakpercayaan pada hukum (distrusting the law) serta adanya penyalahgunaan hukum (misuse of the law). Sejumlah masalah yang layak dicatat berkenaan dengan bidang hukum antara lain:

a. Sistem peradilan yang dipandang kurang independen dan imparsial;

b. Belum memadainya perangkat hukum yang mencerminkan keadilan sosial;

11 Bernard Arief Sidharta, Refleksi tentang Struktur Ilmu Hukum, Bandung: Mandar Maju, 2000, hlm. 189.

12 Moh. Mahfud MD., “Keniscayaan...Op., Cit.., hlm. 4 
c. Inkonsistensi dalam penegakan hukum;

d. Masih adanya intervensi terhadap hukum;

e. Lemahnya perlindungan hukum terhadap masyarakat;

f. Rendahnya kontrol secara komprehensif terhadap penegakan hukum;

g. Belum meratanya tingkat keprofesionalan para penegak hukum; dan

h. Proses pembentukan hukum yang lebih merupakan power game yang mengacu pada kepentingan the powerfull daripada the needy.

Merujuk pada uraian diatas, setidaknya secara konsep yang perlu diwujudkan dalam reformasi hukum dalam rangka mencapai supremasi hukum yang berkeadilan antara lain:

a. Penggunaan hukum yang berkeadilan sebagai landasan pengambilan keputusan oleh aparatur negara;

b. Adanya lembaga pengadilan yang independen, bebas dan tidak memihak;

c. Aparatur penegak hukum yang professional;

d. Penegakan hukum yang berdasarkan prinsip keadilan;

e. Pemajuan dan perlindungan HAM;

f. Partisipasi publik; dan

g. Mekanisme kontrol yang efektif.

Pada dasarnya reformasi hukum harus menyentuh tiga komponen hukum yang disampaikan oleh Lawrence Friedman yang meliputi:

a. Struktur Hukum, dalam pengertian bahwa struktur hukum merupakan pranata hukum yang menopang sistem hukum itu sendiri, yang terdiri atas bentuk hukum, lembaga-lembaga hukum, perangkat hukum, dan proses serta kinerja mereka

b. Substansi Hukum, dimana merupakan isi dari hukum itu sendiri, artinya isi hukum tersebut harus merupakan sesuatu yang bertujuan untuk menciptakan keadilan dan dapat diterapkan dalam masyarakat

c. Budaya Hukum, hal ini terkait dengan profesionalisme para penegak hukum dalam menjalankan tugasnya, dan tentunya kesadaran masyarakat dalam menaati hukum itu sendiri.

Dari segi materi/substansi hukumnya pembenahan perlu dilakukan tidak hanya mencakup kemungkinan mengadopsi pranata-pranata hukum baru yang muncul dalam kerangka globalisasi ekonomi yang dapat memunculkan kecenderungan terjadinya globalisasi hukum, namun juga adaptasi terhadap paradigma baru dalam sistem pemerintahan khususnya berkaitan dengan otonomi daerah, misalnya kemungkinan berlakunya ketentuan-ketentuan hukum adat setempat bagi hubungan-hubungan hukum atau peristiwa-peristiwa hukum tertentu. Pembenahan materi/substansi hukum tersebut bisa dilaksanakan melalui 3 alternatif, yaitu:

a. Merumuskan dan menetapkan ketentuan-ketentuan hukum baru untuk hal-hal yang sama sekali belum diatur; 
b. Melakukan transformasi dari ketentuan-ketentuan hukum internasional menjadi ketentuan hukum nasional melalui instrument pengesahan/ratifikasi perjanjian-perjanjian internasional terkait; dan

c. Memodifikasi ketentuan-ketentuan hukum yang sudah ada untuk mengikuti perkembangan kesadaran dan kebutuhan hukum yang berkembang dalam masyarakat.

Secara umum dalam rangka melakukan reformasi hukum tersebut ada beberapa hal yang harus dilakukan antara lain:

a. Penataan kembali struktur dan lembaga-lembaga hukum yang ada termasuk sumber daya manusia yang berkualitas;

b. Perumusan kembali hukum yang berkeadilan;

c. Peningkatan penegakkan hukum dengan menyelesaikan kasus-kasus pelanggaran hukum; dan

d. Pengikutsertaan rakyat dalam penegakan hukum; dan

e. Pendidikan publik untuk meningkatkan pemahaman masyarakat terhadap hukum; dan

f. Penerapan konsep Good Governance.

Perjalanan reformasi hukum dikatakan belum berhasil optimal melihat realitas penegakan hukum yang terjadi sampai hari ini. Kepastian hukum masih ditegakkan melalui pendekatan peraturan atau undang-undang atau pendekatan legislatif, belum melalui penegakan hukum oleh pengadilan sebagai benteng terakhir masyarakat pencari keadilan atau pendekatan law enforcement dan an independent judiciary. Meskipun supremasi hukum diteriakkan keras-keras, tetapi sejalan dengan itu penghormatan terhadap hukum hanya sebatas formalistik dan prosedural.

Ketidakhormatan terhadap hukum semakin menjadi-jadi manakala hukum hanya dipandang secara tekstual dan sangat positifistik menafikkan aspek keadilan yang menjadi ruhnya. Institusi dan aparatur hukum hanya mengedepankan formal justice semata tanpa memperdulikan substansial justice sehingga segala sesuatu dilihat secara hitam-putih. ${ }^{13}$

Hingga masa pemerintahan sekarang ini, reformasi hukum belum dilaksanakan dengan sungguh-sungguh. Terbukti, masih dilakukannya kebiasaan-kebiasaan lama melalui praktik judicial corruption, tidak tuntasnya masalah penegakan hukum terhadap pelanggaran HAM, dan korupsi.

\section{Perubahan Paradigma: dari Berfikir Hukum Tekstual ke Hukum Progresif}

Sebagaimana diuraikan diatas, struktur hukum (legal structure) yang dalam hal ini adalah polisi, jaksa, hakim, dan pengacara memegang peranan penting dalam melakukan reformasi hukum. Reformasi paradigma dari berfikir hukum tekstual ke hukum progresif harus dilakukan oleh para penegak hukum. Di dalam melakukan penegakan hukum tidak bisa 
dilakukan hanya sebatas formalistik dan prosedural semata. Jika hukum hanya dipandang secara tekstual dan sangat positivistik akan menafikkan aspek keadilan yang menjadi ruhnya.

Hukum progresif adalah sebuah konsep hukum yang tidak terkukung kepada konsep teks Undang-Undang semata, tetapi juga memperhatikan rasa keadilan yang hidup di masyarakat. Namun tidak semua sepakat bahwa hukum itu harus terbuka terhadap sebuah zaman. Aliran pemikiran hukum lain menyatakan bahwa hakim hanyalah corong dari undang-undang (bouche de la loi), sebagaimana dinyatakan oleh Immanuel Kant dan Montesquieu. ${ }^{14}$ Pada tingkatan ini tersirat makna bahwa para penegak hukum tidak lebih dari "robot" pelaksana pasal produk perundangundangan.

a. Cara Berhukum Secara Progressif

Hukum progresif lahir dari rasa ketidakpuasan kalangan hukum terhadap teori dan praktik hukum tradisional yang berkembang. Para penganutnya mengkritisi terhadap begitu besarnya "jurang pemisah" antara hukum yang dipraktikan dengan teori hukum. Hukum dianggap gagal dalam merespon setiap masalah yang terjadi di tengah masyarakat. $^{15}$

Sudah sering terdengar paradok-paradok yang ditujukan kepada aparat penegakan hukum terutama hakim sebagai pemutus suatu perkara mengenai putusan pembebasan para koruptor penjarah uang rakyat yang berjumlah banyak, yang dibebaskan oleh hakim. Tidak jarang pula tuduhan yang menyudutkan aparat penegak hukum yang dianggap mempersulit orang "kebanyakan" untuk mendapatkan keadilan dalam persidangan, selain bukti-bukti yang cukup kuat yang dimiliki olehnya. Masih banyak lagi persoalan yang menyebabkan semakin terpuruknya hukum saat ini. ${ }^{16}$

Penerapan hukum mengalami perubahan dari masa kemasa. Tujuan dari pembenahan ini adalah bagaimana mewujudkan hukum yang substantif sehingga keadilan dapat tercapai. Cara berhukum positifistik sering kali tidak dapat mewujudkan keadilan yang substantif, khususnya bagi para pihak yang lemah dan termarjinalkan. Sistem hukum modern yang bersandarkan kepada semangat liberal dan kapitalisme jelas hanya akan menguntungkan pihak yang kuat, baik secara ekonomi maupun politik. Ciri khas dari sistem hukum modern itu adalah cara berhukum yang terfokus kepada teks undangundang (tekstual approach).

14 Sudikno Mertokusumo, Mengenal... Op., Cit., hlm. 39

15 Munir Fuady, Aliran Hukum Kritis, Paradigma Ketidakberdayaan Hukum, Bandung: Citra Aditya Bahkti, 2003, hlm. 1

16 A.M. Mijahidin, "Hukum Progresif: Jalan Keluar Dari Keterpurukan Hukum Di Indonesia", Majalah Hukum Varia Peradilan, Edisi No 257 April 2007, Jakarta: Ikahi, 2007, hlm. 51 
Oleh karenanya untuk terlepas dari belenggu formalismpositifisme diperlukan cara berhukum baru agar hukum mampu menangkap hakikat akan kebenaran, keadilan dan kemanusiaan.

Perkembangan hukum progresif tidak lepas dari perkembangan tatanan hukum sebagaimana yang dikemukakan oleh Nonet dan Selznick yaitu: ${ }^{17}$ pertama, tatanan hukum yang represif, dimana hukum disubordinasikan di bawah tatanan politik dan tatanan ekonomi, kedua, tatanan hukum yang otonom/mandiri, dimana hukum berkedudukan setara (koordinatif) dengan tatanan politik, tatanan ekonomi dan sosial budaya, sedangkan yang ketiga, tatanan hukum yang responsif, dimana hukum berupaya untuk mendekatkan dirinya kepada kebutuhan sosial dari suatu masyarakat.

Berbagai bangsa memiliki seni dan keanekaragaaman dalam memahami dan melaksanakan hukum di negaranya. Kendati samasama menyebutnya sebagai negara hukum, tetapi kita tidak akan menemukan cara yang seragam dalam berhukum itu. Potret keanekaragaman cara berhukum itu hanya meneguhkan pendapat, bahwa cara bangsa berhukum itu tidak bisa terlepas dari akar-akar sosial dan kulturnya. ${ }^{18}$

Dengan demikian hukum progresif merubah cara berhukum dari sekedar menerapkan hukum positif secara tekstual menjadi cara berhukum dengan mendayagunakan hukum dengan tujuan, misi dan dimensi spiritual dan sosial. Aturan formal semata bila diaplikasikan di lembaga peradilan dimana hakim-hakimnya juga berpandangan legal-positifistik dikhawatirkan akan memberangus gugatan yang bersubtansikan visi bantuan hukum struktural dalam rangka memperjuangkan hak asasi manusia, keadilan dan demokrasi. Oleh karena itu hakim harus membuat terobosan untuk membuat penemuan hukum dalam konteks visi terwujudnya keadilan substanstif.

Dalam perspektif hukum progresif para penegak hukum dituntut untuk melakukan lompatan lebih dari sekedar tugas dan kewenangan yang diberikan oleh teks aturan formal.

b. Kewenangan Diskresi Penegak Hukum

Menurut Kamus Hukum, diskresi berarti kebebasan mengambil keputusan dalam setiap situasi yang dihadapi menurut pendapatnya sendiri. ${ }^{19}$ Diskresi adalah kebijakan dari pejabat yang intinya membolehkan pejabat publik melakukan sebuah kebijakan dimana undang-undang belum mengaturnya secara tegas, dengan tiga syarat, yakni demi kepentingan umum, masih dalam batas wilayah

17 Philipe Nonet dan Plipi Selznick, Law \& Society in Transition: Tower Responsive Law, Alih Bahasa: Rafel Edy Bosco, Jakarta: HuMa, 2003, hlm. 59-60

is Satjipto Rahardjo, Biarkan Hukum Mengalir; Catatan Kritis Tentang Pergulatan Manusia Dengan Hukum, Jakarta: Penerbit Buku Kompas, 2007, hlm. 65

19 JCT Simorangkir dkk, Kamus Hukum, Jakarta: Penerbit Sinar Grafika, 2008, hlm. 38 
kewenangannya, dan tidak melanggar Asas-Asas Umum Pemerintahan yang Baik (AUPB). ${ }^{20}$

Ada beberapa pakar hukum yang memberikan definisi diskresi diantaranya S. Prajudi Atmosudirjo yang mendefinisikan diskresi, discretion (Inggris), discretionair (Perancis), freies ermessen (Jerman) sebagai kebebasan bertindak atau mengambil keputusan dari para pejabat administrasi negara yang berwenang dan berwajib menurut pendapat sendiri. ${ }^{21}$ Selanjutnya dijelaskannya bahwa diskresi diperlukan sebagai pelengkap dari asas legalitas, yaitu asas hukum yang menyatakan bahwa setiap tindak atau perbuatan administrasi negara harus berdasarkan ketentuan Undang-Undang. Akan tetapi tidak mungkin bagi Undang-Undang untuk mengatur segala macam kasus posisi dalam praktek kehidupan sehari-hari.

Sjachran Basah mengatakan bahwa freies ermessen adalah kebebasan untuk bertindak atas inisiatif sendiri, akan tetapi dalam pelaksanaannya haruslah tindakan-tindakan administrasi negara itu sesuai dengan hukum, sebagaimana telah ditetapkan dalam negara hukum berdasarkan Pancasila. ${ }^{22}$ Sedangkan Diana Halim Koentjoro mengartikan freies ermessen sebagai kemerdekaan bertindak administrasi negara atau pemerintah (eksekutif) untuk menyelesaikan masalah yang timbul dalam keadaan kegentingan yang memaksa, dimana peraturan penyelesaian untuk masalah itu belum ada. ${ }^{23}$

Berdasarkan doktrin-doktrin hukum tersebut diatas, maka dapat disimpulkan bahwa pada hakekatnya diskresi merupakan kebebasan bertindak atau kebebasan mengambil keputusan dari Badan atau pejabat administrasi pemerintahan menurut pendapatnya sendiri sebagai pelengkap dari asas legalitas, manakala hukum yang berlaku tidak mampu menyelesaikan permasalahan tertentu yang muncul secara tiba-tiba, bisa karena peraturannya memang tidak ada atau karena peraturan yang ada yang mengatur tentang sesuatu hal tidak jelas.

Dalam konteks penegakan hukum, pemikiran hukum progresif memberikan ruang yang luas kepada para penegak hukum dalam hal ini polisi dan jaksa untuk melakukan diskresi. Sebagaimana diuraikan diatas, bahwa diskresi dilakukan dengan penuh pertimbangan yang mendalam dengan tiga syarat yaitu demi kepentingan umum yang menyangkut persoalan-persoalan penting yang mendesak, masih dalam batas wilayah kewenangannya, dan tidak melanggar Asas-Asas

20 M. Sofyan Lubis, "Fenomena Diskresi vs Korupsi” http://www.sofyanlubis. blogspot.com/2009/04/fenomena-diskresi-vs-korupsi.html, diakses tanggal 12 Nopember 2017

21 S. Prajudi Atmosudirjo, Hukum Administrasi Negara, Jakarta: Ghalia Indonesia, 1994, hlm. 82

22 Sjachran Basah, Eksistensi dan Tolok Ukur Peradilan Administrasi Negara di Indonesia, Bandung: Alumni, 1997, hlm. 3

23 Diana Halim Koentjoro, Hukum Administrasi Negara, Bogor: Ghalia Indonesia, 2004, hlm. 41 
Umum Pemerintahan yang Baik. Lebih jauh lagi adalah untuk mendapatkan keadilan substantif.

Marcus Lukman sebagaimana dikutip oleh Saut P Panjaitan ${ }^{24}$ mengatakan bahwa persoalan-persoalan penting yang mendesak, sekurang-kurangnya mengandung unsur-unsur sebagai berikut :

a. Persoalan-persoalan yang muncul harus menyangkut kepentingan umum, yaitu: kepentingan bangsa dan negara, kepentingan masyarakat luas, kepentingan rakyat banyak/bersama, serta kepentingan pembangunan;

b. Munculnya persoalan tersebut secara tiba-tiba, berada diluar rencana yang telah ditentukan;

c. Untuk menyelesaikan persoalan tersebut, peraturan perundangundangan belum mengaturnya atau hanya mengatur secara umum, sehingga pejabat administrasi negara mempunyai kebebasan untuk menyelesaikan atas inisiatif sendiri;

d. Prosedurnya tidak dapat diselesaikan menurut administrasi yang normal, atau jika diselesaikan menurut prosedur administrasi yang normal justru kurang berdaya guna dan berhasil guna; dan

e. Jika persoalan tersebut tidak diselesaikan dengan cepat, maka akan menimbulkan kerugian bagi kepentingan umum.

Dengan adanya freies ermessen ini berarti bahwa sebagian kekuasaan yang dipegang oleh badan pembentuk undang-undang dipindahkan ke dalam tangan pemerintah/administrasi negara, sebagai badan eksekutif. Jadi supremasi badan legislatif diganti oleh supremasi badan eksekutif, ${ }^{25}$ karena administrasi negara melakukan penyelesaian masalah tanpa harus menunggu perubahan UndangUndang dari legislatif. ${ }^{26}$ Hal tersebut karena pada prinsipnya Badan/Pejabat administrasi pemerintahan tidak boleh menolak untuk memberikan pelayanan kepada masyarakat dengan alasan hukumnya tidak ada ataupun hukumnya ada tetapi tidak jelas, sepanjang hal tersebut masih menjadi kewenangannya.

Dalam konteks ini diperlukan para penegak hukum yang dalam hal ini adalah polisi dan jaksa untuk berani melangkah pada pemikiran hukum yang progresif, sehingga hukum yang berkeadilan sebagaimana yang dicita-citakan negara hukum dapat tercapai.

\section{Penegakan Hukum yang Berkeadilan}

Seringkali penegakan hukum tekanannya hanya selalu diletakkan pada aspek ketertiban semata. Hal ini mungkin sekali disebabkan oleh karena

24 Marcus Lukman sebagaimana dikutip oleh Saut P. Panjaitan, Makna dan Peranan Freies Ermessen Dalam Hukum Administrasi Negara dalam SF Marbun dkk, Dimensi-Dimensi Pemikiran Hukum Administrasi Negara, Yogyakarta: UII Press, 2001, hlm. 117

25 A. Siti Soetami, Hukum Administrasi Negara, Semarang: Badan Penerbit Universitas Diponegoro, 2000, hlm. 46

26 Diana Halim Koentjoro, Hukum... Op.,Cit., hlm. 42 
hukum diidentikkan dengan penegakan perundang-undangan, asumsi seperti ini adalah sangat keliru, karena hukum itu harus dilihat dalam satu sistem, yang menimbulkan interaksi tertentu dalam berbagai unsur sistem hukum yang tidak hanya mengacu pada aturan (codes of rules) dan peraturan (regulations), namun mencakup bidang yang luas, meliputi struktur, lembaga dan proses (procedure) yang mengisinya serta terkait dengan hukum yang hidup dalam masyarakat (living law) dan budaya hukum (legal culture).

Dalam konteks penegakan hukum, budaya hukum (legal culture) menjadi elemen yang sangat penting. Budaya hukum adalah meliputi pandangan, kebiasaan maupun perilaku dari masyarakat mengenai pemikiran nilai-nilai dan pengharapan dari sistem hukum yang berlaku, dengan perkataan lain, budaya hukum itu adalah iklim dari pemikiran sosial tentang bagaimana hukum itu diaplikasikan, dilanggar atau dilaksanakan. Setiap masyarakat, negara dan komunitas mempunyai budaya hukum sendiri yang dipengaruhi nilai-nilai budaya yang hidup dimasyrakat baik itu sukusuku atau adat maupun pengaruh agama.

Melihat kenyataan yang demikian, para penegak hukum semestinya tidak boleh hanya mengedepankan aspek hukum formil semata. Penegakan hukum yang hanya bertitik tolak dari substansi norma hukum formil yang ada dalam undang-undang (law in book's), akan cenderung mencederai rasa keadilan masyarakat. Seyogyanya penekanannya harus juga bertitik tolak pada hukum yang hidup (living law). Lebih jauh para penegak hukum harus memperhatikan budaya hukum (legal culture), untuk memahami sikap, kepercayaan, nilai dan harapan serta pemikiran masyarakat terhadap hukum dalam sistem hukum yang berlaku.

Tujuan hukum secara teoretis mencakup tiga hal yaitu keadilan, kepastian, dan kemanfaatan. Keadilan dapat dikatakan sebagai tujuan utama yang bersifat universal. Keadilan memang merupakan konsepsi yang abstrak, namun demikian di dalam konsep keadilan terkandung makna perlindungan hak, persamaan derajat dan kedudukan di hadapan hukum, serta asas proporsionalitas antara kepentingan individu dan kepentingan sosial. Sifat abstrak dari keadilan adalah karena keadilan tidak selalu dapat dilahirkan dari rasionalitas, tetapi juga ditentukan oleh atmosfir sosial yang dipengaruhi oleh tata nilai dan norma lain dalam masyarakat. Oleh karena itu keadilan juga memiliki sifat dinamis yang kadang-kadang tidak dapat diwadahi dalam hukum positif. ${ }^{27}$

Dari konsepsi di atas terlihat bahwa penegakan hukum yang berkeadilan harus mencakup hal-hal sebagai berikut yaitu:

a. Perlindungan HAM;

b. Persamaan derajat dan kedudukan di hadapan hukum; dan

27 Moh. Mahfud MD., "Penegakan Hukum dan Tata Kelola Pemerintahan Yang Baik”, Bahan pada Acara Seminar Nasional "Saatnya Hati Nurani Bicara" yang diselenggarakan oleh DPP Partai HANURA, Jakarta, 8 Januari 2009, hlm. 2-3 
c. Asas proporsionalitas antara kepentingan individu dan kepentingan sosial.

Untuk mewujudkan hukum yang berkeadilan dibutuhkan reformasi dari penegak hukum itu sendiri baik itu reformasi institusi maupun reformasi dari individu para penegak hukumnya. Reformasi institusi yang ideal harus mengacu pada tiga orientasi utama, yaitu prinsip demokrasi, rule of law, dan hak asasi manusia.

Prinsip democratic oversight menegaskan bahwa dalam menjalankan peran dan fungsinya, penegak hukum harus menjunjung tinggi prinsip transparansi, akuntabilitas, responsif, kontrol institusi demokratik yang merupakan representasi kepentingan publik, dan membuka partisipasi masyarakat luas. ${ }^{28}$ Dalam hal reformasi institusi kepolisian misalnya, merujuk pada konsep democratic policing paling tidak reformasi kepolisian terdiri dari enam pilar yang saling bergantung, yaitu; kontrol internal institusi keamanan (kepolisian) bersangkutan, kontrol pemerintah/eksekutif, pengawasan parlemen, pengawasan yudisial (judicial oversight), dan pengawasan masyarakat sipil (civil society oversight). ${ }^{29}$

Reformasi institusi penegak hukum harus ditujukan untuk memperkuat rule of law. Prinsip rule of law meniscayakan adanya suatu komitmen terhadap norma hak asasi manusia. ${ }^{30}$ Reformasi institusi berbasis rule of law menegaskan bahwa seorang penegak hukum tidak hanya harus menegakkan hukum berdasarkan ketentuan hukum positif yang berlaku, tetapi harus sensitif terhadap asas keadilan dan kemanusiaan.

Reformasi institusi penegak hukum di era di mana demokrasi diakui sebagai dasar fundamentalnya, tidak bisa mengabaikan standar HAM yang berlaku baik sebagai tolak ukur akuntabilitas kepada pihak eksternal, maupun sebagai panduan tata kelola internal institusi. Standar HAM yang dimaksud adalah segala aturan dan ketentuan yang tertuang diberbagai instrumen HAM internasional, khususnya yang bersifat legally binding (mengikat secara hukum) bagi negara-negara yang telah meratifikasinya. ${ }^{31}$

Selanjutnya reformasi institusi penegak hukum harus memperhatikan pentingnya terintegrasinya criminal justice system dalam kerangka penegakan hukum. Praktik mafia peradilan selalu diikuti oleh adanya penyalahgunaan wewenang (korupsi) oleh aparat hukum. Sementara pemberantasan korupsi cenderung alpa terhadap kaitan antar criminal justice system, di mana agenda pemberantasan korupsi cenderung fokus pada kasus-kasus besar dan terhadap korupsi di kepolisian, kejaksaan serta kehakiman (pengadilan). Kurangnya dukungan anggaran yang diberikan oleh negara seringkali dimanfaatkan dan dijadikan justifikasi oleh aparat

28 Senior Police Adviser to the OSCE Secretary General, Guidebook on Democratic Policing, OSCE, 2006, Vienna, hlm 10, dalam Koalisi Reformasi Polri, "Reformasi Kepolisian Republik Indonesia Menuju Pemolisian yang Demokratis", hlm. 2

\footnotetext{
29 Ibid.

30 Ibid., hlm. 3

31 Ibid.
} 
penegak hukum untuk mencari sumber pendanaan ilegal untuk kepentingan pribadi dan mengakibatkan terjadinya diskriminasi kepada masyarakat. ${ }^{32}$

\section{Harapan Penegakan Hukum Di Indonesia}

Di bidang struktur hukum, dibutuhkan keberanian untuk berhijrah dari para penegak hukum dari cara berfikir hukum tekstual ke hukum progresif demi menghadirkan keadilan yang substantif.

Sistem Hukum di Indonesia sangat tergantung pada aparatur penegak hukum antara lain Polri, Kejaksaan, Kehakiman dan lembaga-lembaga penegak hukum terkait sebagai pilar dalam melaksanakan penegakan hukum. Oleh karena itu, diharapkan antar institusi penegak hukum tersebut secara konsisten dapat menjalin hubungan kerja sama dengan harmonis, sinergis, dan komprehensif yang terintegrasi dalam Criminal Justice System (CJS).

Di bidang substansi hukum, dibutuhkan konsistensi penguatan institusi penegak hukum secara berimbang antara Polri, Kejaksaan, KPK, Kehakiman (MA dan MK) dan Lembaga Advokat dalam penegakan hukum, agar tidak terjadi perbedaan kewenangan yang dominan antar institusi penegak hukum yang satu dengan yang lain, sehingga tidak terjadi pelemahan secara sistematis terhadap institusi penegak hukum tertentu. Oleh karena itu, diharapkan dilakukan peninjauan kembali terhadap ketentuan peraturan perundang-undangan terutama yang mengatur masalah kewenangan masing-masing institusi penegak hukum.

Di bidang budaya hukum, pembenahan budaya hukum di Indonesia perlu dilakukan baik terhadap aparat penegak hukum di satu pihak yang cenderung menegakkan hukum dengan mengedepankan kepastian hukum, maupun terhadap masyarakat di pihak yang lain yang cenderung menekankan padarasa keadilan. Oleh karenanya terjadi ambivalensi dalam penegakan hukum, sehingga diharapkan aparat penegak hukum mampu memberikan penilaian berdasarkan pertimbangan sosiologis untuk melakukan tindakan agar rasa keadilan masyarakat dapat terpenuhi.

Penegakan hukum di Indonesia seringkali terjadi intervensi dan kooptasi yang dilakukan oleh pihak-pihak yang memiliki kepentingan dengan perkara yang sedang ditangani, sehingga berakibat terganggunya independensi aparat penegak hukum dalam menyelesaikan perkara. Berkenaan dengan hal tersebut, diperlukan transparansi pada setiaptindakan dalam penegakan hukum.

\section{SIMPULAN}

Dalam konteks reformasi institusi penegakan hukum, perubahan paradigma baru yang lebih mengedepankan nilai-nilai hak asasi manusia dan nilai-nilai demokrasi diharapkan dapat membawa institusi penegak hukum menjadi sebuah institusi yang transparan dan akuntabel, serta menampilkan wajah sebagai aparat

32 Ibid.,hlm. 8 
penegak hukum yang profesional dalam melaksanakan tugasnya. Perubahan paradigma baru tersebut harus dibarengi perubahan cara berfikir dari hukum tektual ke hukum progresif. Hal ini dapat diwujudkan apabila reformasi institusi penegak hukum konsisten dalam mewujudkan perubahan pada aspek kultural yang merupakan muara dari perubahan aspek struktural dan instrumental, yang terwujud dalam bentuk kualitas pelayanan kepada masyarakat.

Akhirnya harus diingat bahwa hukum senantiasa tertuju pada tiga tujuan utama yaitu kepastian hukum (yuridis), keadilan (filosofis), dan kemanfaatan atau kegunaan (sosiologis). Ketiga tujuan hukum tersebut harus termanisfestasi dalam peraturan perundang-undangan hingga pelaksanaan dalam praktek hukum. Oleh sebab itu, maka para aparat penegak hukum harus menyadari hal itu sehingga mampu mewujudkan ketiga tujuan hukum itu dengan baik dan sungguh-sungguh.

\section{DAFTAR PUSTAKA}

\section{Buku :}

Ali, Ahmad. 2008. Menguak Tabir Hukum (Suatu Kajian Filosofis dan Sosiologis), Makasar: Universitas Hassanudin

Atmosudirjo, S. Prajudi. 1994. Hukum Administrasi Negara, Jakarta: Ghalia Indonesia

Basah, Sjachran. 1997. Eksistensi dan Tolak Ukur Peradilan Administrasi Negara di Indonesia, Bandung: Alumni

Black, Henry Campbell, 1990. Black's Law Dictionary, Edisi VI, St. Paul Minesota: West Publishing

Cunningham, W. Tharp. 1982. Nelson Contemporary English Dictionary, Canada: Thompson and Nelson Ltd

Friedman, Lawrence M. 2001. American Law An Introduction, 2nd Edition (Hukum Amerika: Sebuah Pengantar, Penerjemah: Wisnu Basuki), Jakarta: Tatanusa

Fuady, Munir. 2003. Aliran Hukum Kritis, Paradigma Ketidakberdayaan Hukum, Bandung: Citra Aditya Bahkti

Koentjoro, Diana Halim. 2004. Hukum Administrasi Negara, Bogor: Ghalia Indonesia

Kusumaatmadja, Mochtar. 2006. Konsep-Konsep Hukum Dalam Pembangunan, Bandung: Alumni

Marbun, SF., dkk. 2001. Dimensi-Dimensi Pemikiran Hukum Administrasi Negara, Yogyakarta: UII Press

Mertokusumo, Sudikno. 1991. Mengenal Hukum, Yogyakarta: Liberty

Muladi. 2002. Hak Asasi Manusia, Politik dan Sistem Peradilan Pidana, Cet. II, Semarang: Badan Penerbit Universitas Diponegoro 
Nonet, Philipe, dan Plipi Selznick, 2003. Hukum Responsis Pilihan Dimasa Taransisi, Rafel Edy Bosco (penerjemah), Jakarta: HuMa

Rahardjo, Sajipto. 2007. Biarkan Hukum Mengalir; Catatan Kritis Tentang Pergulatan Manusia Dengan Hukum, Jakarta: Penerbit Buku Kompas

2009. Hukum Progresif, Sebuah Sintesa Hukum Indonesia, Yogyakarta: Genta Publishing

Sidharta, Bernard Arief. 2000. Refleksi tentang Struktur Ilmu Hukum, Bandung: Mandar Maju

Simorangkir, JCT., dkk. 2008. Kamus Hukum, Jakarta: Penerbit Sinar Grafika

Soekanto, Soerjono. 2007. Faktor-Faktor yang Mempengaruhi Penegakan Hukum, Jakarta: PT RajaGrafindo Persada

Soetami, A. Siti. 2000. Hukum Administrasi Negara, Semarang: Badan Penerbit Universitas Diponegoro

Susanto, Anthon F., Membaca Mitos Hukum Ditengah Percepatan Perubahan, Tulisan yang diajukan untuk Penerbitan Buku "Menyambut 70 Tahun Usia Prof. Satjipto Rahardjo.

\section{Karya Ilmiah berupa Disertasi, Tesis, Skripsi, Makalah, Seminar, Lokakarya :}

Koalisi Reformasi Polri (ICJR, ICW, IDSPS, Imparsial, INFID, KontraS, LBH Jakarta, Praxis, ProPatria, P2D ), "Reformasi Kepolisian Republik Indonesia Menuju Pemolisian yang Demokratis".

M. D, Mahfud, "Penegakan Hukum dan Tata Kelola Pemerintahan Yang Baik" Bahan pada Acara Seminar Nasional "Saatnya Hati Nurani Bicara" yang diselenggarakan oleh DPP Partai HANURA. Jakarta, 8 Januari 2009

M. D, Mahfud, Moh, Keniscayaan Reformasi Hukum : Upaya Menjaga Jati Diri Dan Martabat Bangsa, Makalah dalam Konvensi Kampus VI dan Temu Tahunan XII Forum Rektor Indonesia (FRI) di Universitas Tanjungpura Pontianak, 9 Januari 2010

\section{Artikel dalam Jurnal, Majalah, Surat Kabar, dan Internet :}

Lubis, M. Syofyan, “ Fenomena Diskresi vs Korupsi”, http://www.sofyanlubis.blogspot.com/2009/04/fenomena-diskresi-vs-korupsi.ht $\underline{\mathrm{ml}}$, diakses 12 Nopember 2011

Mijahidin, A. M. "Hukum Progresif: Jalan Keluar Dari Keterpurukan Hukum Di Indonesia", Majalah Hukum Varia Peradilan, Edisi No 257 April 2007, Jakarta: Ikahi 